\title{
P四四
}

\section{Twitter as a Polarized Space for Civil Society Organizations (CSOs) in Turkey}

\author{
Sema Akboğa \\ Engin Arrk
}

\begin{abstract}
Research on the coverage of CSOs on social media and the use of social media by CSOs has been gaining momentum. To contribute to this line of research, this study investigates the coverage of civil society organizations (CSO) on Twitter in Turkey by focusing on the most frequently mentioned organizations. It examines the characteristics of these CSOs as well as the effect that social and political developments in Turkey have on their coverage on Twitter. The data were collected from Twitter for the period between August 18, 2019 and September 17, 2019. We found that CSOs were not equally mentioned on Twitter; a total of 29,387 tweets mentioned 4,941 different CSOs, representing only $3.98 \%$ of all CSOs in Turkey. We also found that, with a few exceptions, tweets were not equally distributed in number across the CSOs or over time. Furthermore, the content of the tweets about the most frequently mentioned CSOs was strongly related to the political developments in Turkey, thereby reflecting the politically polarized views about the organizations in Turkey. Therefore, we concluded that ideological divisions in politically polarized countries such as Turkey shape the coverage of CSOs on Twitter.
\end{abstract}

Keywords: Turkey, CSOs, Twitter, polarization, democracy.

Öz: Sosyal medyada sivil toplum kuruluşlarının (STK) ne kadar yer aldığı ve sosyal medyanın sivil toplum kuruluşları tarafından kullanılması üzerine araştırmaların sayısı artmaktadır. Bu alandaki çalışmalara katkı vermek amacıyla, bu araştırma, Türkiye'de Twitter'da en çok adı geçen STK'ları inceleyerek bu STK'lardan ne kadar bahsedildiğini ve bahsedilen STK'ların özelliklerini ortaya çıkarmayı hedeflemektedir. Bunu yaparken, STK'lardan bahsedilme sıklığının Türkiye'deki sosyal ve siyasi gelişmelerden ne kadar etkilendiğini araştırmaktadır. Bu amaçla, 18 Ağustos 2019 ve 17 Eylül 2019 tarihleri arasında yazılmış tweetler incelenmiştir. Analizler, Türkiye'de STK'lardan Twitter'da sayısal olarak eşit bir şekilde bahsedilmediğini göstermiştir. Dernek ya da vakıflardan bahseden toplam 29.387 tweet vardır ve bu tweetlerde 4.941 dernek ya da vakıftan bahsedilmiştir. Bu da Türkiye'de bulunan STK'ların sadece \%3,98'inden Twitter'da bahsedildiğine işaret etmektedir. Buna ek olarak, birkaç istisna dışında, STK'lar ile ilgili yazılmıș tweetler zaman içinde eşit dağılmamıştır. Ayrıca, bu araștırma STK'lar ile ilgili yazılan tweetlerin Türkiye'deki siyasi gelişmelerle ilişkili olduğunu ve dolayısıyla Türkiye'deki bu kuruluşlarla ilgili siyasi açıdan kutuplaşmış görüşleri yansıttığıni göstermiştir. Bu nedenle, Türkiye gibi siyasi kutuplaşmanın yüksek olduğu ülkelerde ideolojik ayrımların Twitter'da STK'lardan bahsedilmesi üstünde belirleyici bir etkisi olduğu sonucuna varılmıştır. Anahtar Kelimeler:Türkiye, STK, Twitter, kutuplaşma, demokrasi.

We would like to thank Erva Kaygun, Beyza Nur Çalış, İrem Yavuz, and Funda Karadeniz for their contribution to the data coding.

(a)

Assist. Prof., İstanbul Medipol University. semaakboga@gmail.com

Assoc. Prof., Nuh Naci Yazgan University. enginarik@enginarik.com

(iD) http://orcid.org/0000-0003-0937-9961

http://orcid.org/0000-0002-0981-257X

(C) İlmi Etüdler Derneği

DOI: 10.12658/M0439

insan \& toplum, 2020.

insanvetoplum.org
Başvuru: 16.01.20

世曲 Revizyon: 06.02.20

Kabul: 01.04.20

Online Basım: 17.05. 20 


\section{Introduction}

The relationship between civil society organizations (CSOs) and democracy has been well-established (Diamond, 1994; Putnam, 2000; Paxton, 2002). A variety of social institutions and actors enable CSOs to make democratic contributions to society. One of them is the media, including both traditional and social media. Media coverage of CSOs plays an important role in helping them realize their goals, such as by affecting public opinion and the state's policies. The literature on various issues regarding the coverage of CSOs by traditional media such as newspapers is well-developed (Hale, 2007; Marberg et al., 2016; Waisbord, 2011; Greenberg \& Walters, 2004). Recently, research on the coverage of CSOs on social media and the use of social media by CSOs has been gaining momentum. To contribute to this line of research, in this study we explore the coverage of CSOs on Twitter in Turkey by focusing on the most frequently mentioned CSOs and their characteristics. We investigate how social and political developments taking place in Turkey at the time of writing of these tweets about CSOs influence what Twitter users say about these organizations. In doing so, it reveals how and to what extent CSOs in politically polarized countries such as Turkey, in which CSOs are also politically divided, are mentioned on Twitter. This research therefore contributes to the existing literature on CSOs, social media, and politics.

\section{CSOs and the Media}

CSOs make many contributions to democracy (Diamond, 1994; Putnam, 2000; Paxton, 2002; Dodge, 2015; Foa \& Ekiert, 2017) and the media helps CSOs contribute to democracy in various ways (Andrews \& Caren, 2010; Waisbord, 2011; Waters \& Tindall, 2011; Thornton 2006; Helmig et al., 2012; Marberg et al., 2016). The well-developed literature on the relationship between CSOs and traditional media looks mainly at the publicity that CSOs receive, especially in newspapers. A group of research explores the factors affecting the visibility of CSOs in newspapers (Andrews \& Caren, 2010; Helmig et al., 2012), while other research examines how newspapers frame and present CSOs (Waisbord, 2011; Marberg et al., 2016). The literature on the relationship between CSOs and social media has also been growing recently. Social media tools such as Facebook, Twitter, YouTube, blogs, and online forums offer many advantages for CSOs such as the ability to quickly share opinions, dispense knowledge, and create awareness of issues (Young, 2017). Social media supports the image of CSOs and increases their donations (Seoa, Kim, \& Yang, 2009), as well as facilitates CSOs' advocacy, accountability, and information delivery (Lee, 
Chen, \& Zhang, 2001). Social media is also a low-cost way of mobilizing supporters, initiating interactions with a large group of people, and drawing attention to issues that may not interest traditional media (Botree \& Seltzer, 2009; Lovejoy et al., 2012). Unlike with reports, websites, and e-newsletters, CSOs can use social media to engage in two-way communication with their stakeholders (Walker et al., 2010). Through social media, CSOs engage in real conversations with stakeholders and acquire real-time feedback (Kim et al., 2014). However, research showed that CSOs use mostly one-way communication on social media (Waters \& Jamal, 2011; Waters \& Williams, 2011), indicating that CSOs do not use social media effectively (Bortree \& Seltzer, 2009; Greenberg \& MacAulay, 2009).

There are mainly three issues that research on the relationship between CSOs and social media explores: (1) the extent to which CSOs use social media in their work; (2) CSOs' goals in using social media; and (3) the effectiveness of the use of social media by CSOs in terms of achieving their goals (Lam \& Nie, 2020). A line of research investigates the effect that various factors, such as the organization's size, age, financial resources, and dependence on government or private funding, have on the extent to which CSOs use social media (Lam \& Nie, 2020; Chalmers \& Shotton, 2016; Bortree \& Seltzer, 2009; Zornet et al., 2013; Nah \& Saxton, 2012; Gao, 2016; Miller, 2011). Other research is interested in why CSOs use social media (Greenberg \& MacAulay, 2009; Obar, Zube, \& Lampe, 2012; Zhou \& Pan, 2016).

Lovejoy and Saxton (2012) found that social media has three main functions for CSOs: information, community, and action. Tweets that contain information about the organization's activities, event highlights, or any other news, facts, or reports fulfill the information function of Twitter. Tweets that enable CSOs to interact, share, and converse with stakeholders and, therefore, create more opportunities for the two-way exchange of information and public and open dialogue fulfill the community function of Twitter. Tweets that aim to get followers to do something for the organization, such as donating money, attending events, and engaging in advocacy campaigns, fulfill the action function of Twitter (Lovejoy \&Saxton, 2012). The action function of social media is especially important for the role played by CSOs in digital activism which is defined as the use of social media and other web-based technologies in campaigns for social and political change (Joyce, 2010). Research however showed that CSOs do not use the action function of Twitter as much as its other functions (Lam and Nie, 2020), which means that CSOs do not effectively use Twitter for digital activism. Organizational capacity has an effect on whether a CSO uses tweets with predominantly informational or action content (Anagnostopoulos et al., 2017). 


\section{Media Publicity of CSOs in Turkey}

The number of research on media publicity of CSOs in Turkey has been recently increasing. Previous research revealed that, in Turkey, not all types of CSOs are equally visible in the media (Deren Van Het Hof, 2014; TÜSEV, 2013). Tunç (2005) found that printed media was more likely than visual media to cover CSOs. According to the same research, of the printed media, Cumhuriyet made more news about CSOs than Hürriyet (Tunç, 2005). Some research on the media publicity of CSOs in Turkey examined news about CSOs in local and national newspapers (Güran Yiğitbaşı, 2016), while others have investigated the language used in the presentation of CSOs in newspapers (Depeli, 2014). Another research showed that among the six news portal, Zaman had the highest number of news about CSOs (Deren Van Het Hof, 2014). Most of the news in Zaman and Bianet were about the vocational and advocacy organizations, respectively (Deren Van Het Hof, 2014). Yet other research demonstrated the political polarization in the media in terms of the coverage of CSOs by newspapers in Turkey (Akboga and Arik, 2019). Accordingly, anti-government newspapers in Turkey contain more news about secular CSOs than do pro-government newspapers, while pro-government newspapers contain more news about religious/conservative CSOs than do antigovernment newspapers (Akboğa and Arık, 2018; Akboga and Arik, 2019).

Another line of research investigated how CSOs in Turkey use social media to increase their publicity (Onat, 2010; Saatçioğlu, 2017; Dondurucu, 2014). Şardağ 1 (2017) showed that, in Turkey, 57.9\% of CSOs actively use their Twitter accounts, while only $10 \%$ of CSOs have dialogic interactions with their followers. The same research found that CSOs in the fields of education, research, social services, and health actively use Twitter in Turkey. Saatçioğlu (2017) examined the most frequently created content on the Facebook page of Greenpeace Turkey as well as the topic with which the users most frequently engaged. Öztürk and Şardağ 1 (2018) found that CSOs in Turkey use their Facebook pages for corporate communication and design purposes. Other research examined the content of Facebook and Twitter accounts of Green Crescent (Yeşilay) and Red Crescent (Kızılay) (Bozkanat, 2020; Gümüş ve Ağaçc1, 2018). However, there is no research on how people talk about CSOs on Twitter in Turkey. The present study is the first one on this topic. 


\section{Social and Political Polarization on Social Media in Turkey}

Twitter is a public space in which people can freely express their ideas in short messages called tweets. These tweets can be accessed by anyone unless the account holder disables this function. Some features of Twitter, such as the ability to directly contact the user, share hyperlinks, and start discussions through hashtags, have made it one of the most important social media platforms (Bruns, 2011), especially for political participation. Indeed, some scholars argue that social media allows for more participatory democracy by facilitating people's participation in politics (Bekafigo \& McBride, 2013). Social media is also a place in which democratic or anti-democratic actors contest for power and influence (Tucker et al., 2018). Thus, as Sunstein (2001) argued, contemporary media and the internet also promote a culture of polarization in which individuals are more interested in opinions that they support. The polarization, however, produces the "camp-mentality" that weakens independent public opinion and produces disinformation because people with strong political views are more likely to follow news that are compatible with their political beliefs while ignoring the other news (Körösényi, 2013). Most social media users in the U.S. for example think that interactions on social media with people they disagree with are stressful and frustrating because these people are disrespectful and angry (Duggan \& Smith, 2016). Research also revealed that especially political exchanges on social media are generally negative and uncivil, contributing to the polarization (Tucker et al., 2018).

Although social media might be a space of polarization, it is important to highlight the larger context in which polarization is generated. There are different sources and types of political polarization (Körösényi, 2013; McCoy et al., 2018). Most of the research showed that political polarization is a top-down phenomenon directed by political elites (Fiorina et al., 2008; Levendusky, 2010; Körösényi, 2013). Elite polarization can increase mass political polarization (Hetherington, 2002; Abramowitz \& Saunders, 2008). In other words, parties and political elites cause divisions and political polarization among people (Körösényi, 2013). In Turkey as well, political polarization at both mass and elite level is very high (Aydın-Düzgit \& Balta, 2019; Somer, 2019; Yardımc1-Geyikçi, 2014) and it is mostly created and maintained by political elites such as party leaders (McCoy et al., 2018). This polarization is observed in various issues, including people's opinions about state institutions (Örselli, 2016; Sahin \& Akboga, 2019) and representation of CSOs by newspapers (Akboga and Arik, 2019). 
Social media in Turkey is not exempt from political polarization. As of October 2019, Turkey had about 8.33 million Twitter users-the sixth-highest number among all countries in the world (Clement, 2019). Furthermore, in 2018, 39\% of adults in Turkey indicated that social media was their primary source of news (And1 et al., 2019). Twitter became especially popular after the 2013 Gezi protests (during which the mainstream media was silent), as it served as a platform for the spread of news and information (Barberá \& Metzger, 2013). Although social media is frequently used for organizing for social and political purposes (Çetinkaya et al., 2014), it is a polarized platform in Turkey (Bulut \& Yörük, 2017; Erdoğan \& UyanSemerci, 2018). Over half of social media users in Turkey ignore opinions that are in opposition to theirs (Şener et al., 2015) while sixty percent of Twitter users in Turkey follow people who hold opinions similar to their own (Erdoğan \& UyanSemerci, 2018). However, interaction between like-minded individuals on Twitter strengthens group identity while interaction between different-minded people reinforces in-group and out-group affiliation (Yardi \& Boyd, 2010).

Previous research showed that Twitter has become a space of political polarization in Turkey. For example, starting in 2014, Twitter became a space where the conflict between the JDP and the FETÖ, which later attempted a coup in July 2016, could be easily observed (Doğu et. al., 2014). Çobanoğlu (2019) cross-matched the use of words/terms on Twitter which are widely accepted as common political ideas in Turkey (such as "Islamism", "leftism", "socialist", and "nationalism") with public demands (such as "democracy", "rights", "freedom", "faith", "private life", "ownership", "security", "law", and "Constitution"). He found that, in these tweets, people accused others who held opposing views of being insincere and invited them to be more sincere. Additionally, he found that most of the tweets contained content demonstrating grudges, intolerance, and anger. Hatipoğlu et al. (2019) showed that, on Twitter, people's foreign policy attitudes are shaped by their political parties/ideological stances, such as being pro-government, nationalist, or a supporter of the pro-Kurdish movement. Other research revealed that, on Twitter, people were polarized over the issue of Syrian refugees in Turkey (Hatipoğlu et al., 2016). This polarization creates more segregated communities on social media, thereby enabling the distribution of misinformation (And1 et al., 2019). Indeed, research found that, in Turkey, those who use social media are more likely to be misinformed but are more confident about their knowledge (And1 et al., 2019), further increasing the polarization. 
insan \& toplum

\section{Research Questions and Hypotheses}

Research showed that, in Turkey, newspaper coverage of CSOs is low and newspapers cover some CSOs more frequently than they do others (Akboğa and Arık, 2018; Akboga and Arik, 2019). Therefore, we expect that social media coverage of CSOs in Turkey is also low and that CSOs are not equally presented on social media. Our first two hypotheses are as follows:

Hypothesis 1: In Turkey, a small number of CSOs are mentioned on Twitter.

Hypothesis 2: Tweets about CSOs are not equally distributed in number a) across the CSOs and $b$ ) over time.

In addition, both traditional and social media in Turkey have been increasingly politically polarized (Çağlar et al., 2018; Panayırcı et al., 2016). The coverage of CSOs by newspapers in Turkey reflects this polarization. For example, antigovernment newspapers in Turkey cover more news about secular CSOs than do pro-government newspapers, whereas pro-government newspapers cover more news about religious CSOs than do anti-government newspapers (Akboğa and Arık, 2018; Akboga and Arik, 2019). Twitter has been a politically polarized space in Turkey and reflects the discourses produced in politics (Doğu, 2017; Doğu \& Mat, 2019). Therefore, we expect that tweets about CSOs are also politically polarized. Thus, our third hypothesis is as follows:

Hypothesis 3: Tweets about CSOs include politically polarized views about organizations in Turkey.

\section{Methods}

We used an application program interface (API) to collect data from Twitter for 31 days, between 11:59 am on August 18, 2019 and 11:59 am on September 17, 2019. The start date (August 18, 2019) of the data collection was randomly selected and the tweets were retrieved online from this date on as they appeared on Twitter. In other words, it was not a backward data collection process. We collected all of the tweets containing either derneği ("association" in the accusative form in Turkish) or vakfi ("foundation" in the accusative form in Turkish). The data were filtered according to language (Turkish). We then removed duplicates, tweets with RT (retweets), and conversations (replies) so that each tweet/usage had an equal opportunity to contribute to the data. In addition, we excluded tweets containing these words but not referring to real CSOs, such as Ölü Ozanlar Derneği (Dead 
Poets Society) and Sabah Uyanamayanlar Derneği (Association of People Who Cannot Wake Up Early) (metaphoric, fictional, or sarcastic uses of these words).

The data were then converted into xlsx and txt formats for analysis. To test our hypotheses, we coded the data according to the dates of the tweets, the names of the CSOs, the types of CSOs (association vs. foundation), and the headquarter of the CSOs (in Turkey or not). We also examined the content of the tweets to determine whether they included polarized views about CSOs. During the coding of data, we counted all types of the words and common phrase-like word sequences (n-grams) in the tweets to explore the topics and themes. For reliability, some portion of the data was also coded by two more coders who had no training on this topic and intercoder reliability was very high on the names of the CSOs $(98.7 \%$ agreement on the $1 \%$ of the data), the types of the CSOs ( $100 \%$ agreement on the $15 \%$ of the data), and the headquarter of the CSOs (99\% agreement on the $6 \%$ of the data).

We calculated descriptive statistics for the number of tweets according to the types of CSOs, the origin of the CSOs, the most frequently mentioned CSOs, and the dates of the tweets with the help of a corpus linguistic software program called Antconc (Anthony, 2018) and office tools. When necessary, we also computed relative entropies $\left(\mathrm{H}_{\text {rel }}\right)$ to examine the distribution of the data, i.e., how evenly the number of occurrences was distributed across observations (Gries, 2015). $\mathrm{H}_{\text {rel }}$ values could be between 0 (uneven/random distribution) and 1.0 (even/smooth distribution). We then computed the frequencies of the word types and the word sequences (n-grams) to investigate common topics and co-occurrences of the CSOs in the tweets, if any.

In this study, we closely followed the ethical guidelines of the British Psychological Society (2017) and Williams, Burnap, and Sloan (2017). Therefore, although we obtained data containing personal information such as names, phone numbers, and locations, we omitted such information in this article unless it was crucial to the analysis (e.g., the name of the CSO's president, the CSO's political affiliations, or the headquarter of the CSO).

\section{Results}

To test Hypothesis 1, we analyzed all the tweets between August 18 - September 17, 2019. We found a total of 29,387 tweets mentioning 4,941 different CSOs ( $M=5.95$, $\mathrm{SD}=62.70$, Range $=1-3,342)$. Of them, 3,951 (79.9\%) were associations and 990 (20.1\%) were foundations. This finding is not surprising because, in Turkey, there 
are more associations $(119,008$ as of December 28,2019$)$ than foundations $(5,268$ as of August 7, 2019) (General Directorate of Civil Society Relations, 2019; General Directorate of Foundations, 2019). Therefore, the number of CSOs mentioned in the tweets constituted $3.32 \%$ of associations and $18.79 \%$ of foundations in Turkey. These results confirmed Hypothesis 1 - that, in Turkey, a small number of CSOs are mentioned on Twitter.

We also found that 4,736 of the CSOs (95.85\%) mentioned in the tweets were located in Turkey. The remaining 205 CSOs were located outside Turkey. There was a total of 592 tweets $(2.01 \%)$ about those CSOs outside Turkey ( $M=2.85$, SD $=2.58$, Range $=1-42)$. Of them, 125 were associations (61\%) and the rest were foundations (80, 39\%). Friedrich Ebert Stiftung (42) and the Bill \& Melinda Gates Foundation (35) were the most frequently mentioned CSOs. Moreover, 39 of those CSOs were established by the Turkish population living abroad (e.g., Belçika Denizliler Derneği [Association of People from Denizli in Belgium]) or Cyprus (e.g, Lefkoşa Gençlik Derneği [Lefkoşa/Nicosia Youth Association]). These findings suggest that, not surprisingly, people in Turkey write tweets almost exclusively about CSOs related to people living in Turkey.

To test Hypotheses $2 \mathrm{a}$ and $2 \mathrm{~b}$, we examined the distribution of the tweets about the CSOs. We found that the tweets about the CSOs were not equally distributed in number across the CSOs, which supported Hypothesis 2a. A closer examination of the data showed that $57.66 \%$ of the CSOs were mentioned only once (Median $=1$, $\mathrm{n}(1)=2,849$ ). This suggests that although 4,941 CSOs were mentioned on Twitter, a small number of them were mentioned much more frequently than others. As Table 1 shows, half of the tweets in our data (50.17\%) were about 41 CSOs out of a total of 4,941 ((\%o8) (Table 1$)$.

\section{Table 1}

The 41 Most Frequently Mentioned Associations/Foundations (50.17\% of the Entire Data) $(R / C=$ Religious/Conservative)

\begin{tabular}{|l|l|c|c|}
\hline Name & Type & N & \% \\
\hline Ensar Vakfı (Ensar) & Foundation & 3,342 & 11.37 \\
\hline Ülkü Ocakları Eğitim ve Kültür Vakfı (Ülkü) & Foundation & 1,806 & 6.15 \\
\hline Türkiye Gençlik Vakfı (TÜGVA) & Foundation & 1,154 & 3.93 \\
\hline
\end{tabular}




\begin{tabular}{|c|c|c|c|}
\hline $\begin{array}{l}\text { Türkiye Gençlik ve Eğitime Hizmet Vakfı } \\
\text { (TÜRGEV) }\end{array}$ & Foundation & 1,042 & 3.55 \\
\hline Furkan Vakfı (Furkan) & Foundation & 735 & 2.50 \\
\hline Aziz Mahmud Hüdayi Vakfı (Hüdayi) & Foundation & 704 & 2.40 \\
\hline Fikıh Derneği (F1kıh) & Association & 684 & 2.33 \\
\hline Atatürkçü Düşünce Derneği (ADD) & Association & 362 & 1.23 \\
\hline Hoca Ahmed Yesevi Vakfı (Yesevi) & Foundation & 356 & 1.21 \\
\hline TEMA & Foundation & 320 & 1.09 \\
\hline Okçular Vakfı & Foundation & 310 & 1.05 \\
\hline Kulüpler Birliği Vakfı & Foundation & 308 & 1.05 \\
\hline Boşanmış Mağdur Babalar Derneği & Association & 256 & 0.87 \\
\hline Emeklilikte Yaşa Takılanlar Derneği (EYT) & Association & 183 & 0.62 \\
\hline Arama Kurtarma Derneği (AKUT) & Association & 179 & 0.61 \\
\hline Darül-Fünun İlahiyat Vakfı & Foundation & 171 & 0.58 \\
\hline Pir Sultan Abdal Kültür Derneği & Association & 163 & 0.55 \\
\hline Türkiye Diyanet Vakfı & Foundation & 159 & 0.54 \\
\hline Birlik Vakf 1 & Foundation & 151 & 0.51 \\
\hline Radyo ve Televizyon Gazetecileri Derneği & Association & 151 & 0.51 \\
\hline Düz Dünya Derneği & Association & 149 & 0.51 \\
\hline TÜRKEN Vakf1 & Foundation & 146 & 0.50 \\
\hline $\begin{array}{l}\text { Müstakil Sanayi ve İşadamları Derneği } \\
\text { (MÜSİAD) }\end{array}$ & Association & 141 & 0.48 \\
\hline Kizılay Derneği & Association & 140 & 0.48 \\
\hline $\begin{array}{l}\text { Türk Psikolojik Danışma ve Rehberlik } \\
\text { Derneği }\end{array}$ & Association & 130 & 0.44 \\
\hline İsraf1 Önleme Vakf1 & Foundation & 126 & 0.43 \\
\hline İnsan Hakları Derneği (İHD) & Association & 125 & 0.43 \\
\hline Hacı Bektaş Veli Anadolu Kültür Vakfı & Foundation & 114 & 0.39 \\
\hline Çağdaş Yaşam Destekleme Derneği (ÇYDD) & Association & 105 & 0.36 \\
\hline ÖNDER İmam Hatipliler Derneği & Association & 104 & 0.35 \\
\hline Anadolu Gençlik Derneği (AGD) & Association & 96 & 0.33 \\
\hline Beşir Derneği & Association & 93 & 0.32 \\
\hline Ege Orman Vakfı & Foundation & 88 & 0.30 \\
\hline
\end{tabular}




\begin{tabular}{|l|c|c|c|}
\hline $\begin{array}{l}\text { Türkiye Faal Futbol Hakemleri ve } \\
\text { Gözlemcileri Derneği }\end{array}$ & Association & 88 & 0.30 \\
\hline Cumhuriyet Kadınları Derneği & Association & 85 & 0.29 \\
\hline $\begin{array}{l}\text { İnsan Hak ve Hürriyetleri İnsani Yardım } \\
\text { Vakfı (İHH) }\end{array}$ & Foundation & 83 & 0.28 \\
\hline İlim Yayma Vakfı & Foundation & 79 & 0.27 \\
\hline Türk Eğitim Vakfı & Foundation & 79 & 0.27 \\
\hline Türkiye Gazi ve Şehit Aileleri Vakfı & Foundation & 79 & 0.27 \\
\hline Türkiye Maarif Vakfı & Foundation & 79 & 0.27 \\
\hline İzmir Turizm Tanıtım Vakfı & Foundation & 78 & 0.27 \\
\hline TOTAL & & 14,743 & $\mathbf{5 0 . 1 9}$ \\
\hline
\end{tabular}

We then tested Hypothesis $2 \mathrm{~b}$. As Figure 1 shows, the overall distribution of the data appeared to be relatively even $\left(\mathrm{H}_{\text {rel }}=.92\right)$. However, there was an apparent outlier on August 27, 2019, which consisted of $21.1 \%$ of the entire data. When we excluded this date, the distribution of the data appeared to be much more even (from $\mathrm{M}=942.22, \mathrm{SD}=998.5, \mathrm{H}_{\text {rel }}=.92$ to $\mathrm{M}=767.03, \mathrm{SD}=217.05, \mathrm{H}_{\text {rel }}=.99$ ), which failed to support Hypothesis $2 \mathrm{~b}$.

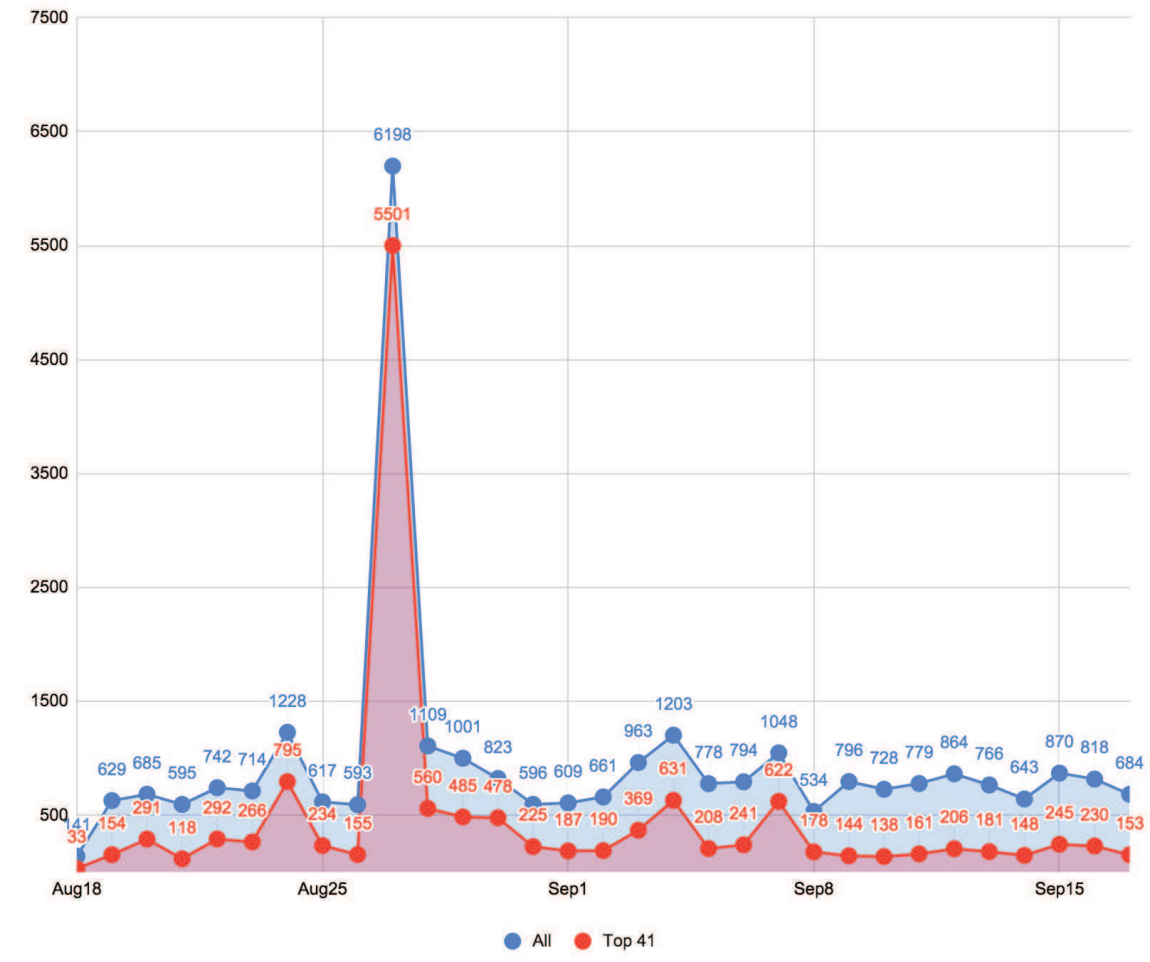


Figure 1. The distribution of tweets mentioning all CSOs $\left(\mathrm{H}_{\text {rel }}=.92\right)$ and the 41 most frequently mentioned CSOs $\left(\mathrm{H}_{\text {rel }}=.79\right)$ by Date.

We further tested Hypothesis $2 \mathrm{~b}$ using the data from the 41 most frequently mentioned CSOs. As Figure 1 shows, the distribution of the data over time was still relatively even $\left(\mathrm{H}_{\text {rel }}=.79\right)$ but was less even compared to the overall data $\left(\mathrm{H}_{\text {rel }}=.92\right)$. Yet, the outlier was more apparent because $88.71 \%$ of the tweets about the 41 most frequently mentioned CSOs were written on August 27, 2019. When we excluded this date, similar to what we observed in the findings about the entire data, the distribution of the data from these 41 CSOs appeared to be much more even (from $\mathrm{M}=475.61, \mathrm{SD}=952.44, \mathrm{H}_{\text {rel }}=.79$ to $\mathrm{M}=307.43, \mathrm{SD}=177.15, \mathrm{H}_{\text {rel }}=.95$ ). Thus, the results for the 41 most frequently mentioned CSOs did not support Hypothesis $2 \mathrm{~b}$ because the data were distributed relatively evenly (with the exception of outliers).

As mentioned above, half of the tweets in our data (50.17\%) were about 41 out of 4,941 CSOs, indicating that most of the CSOs were rarely mentioned in tweets. Therefore, to categorize the organizations, we focused on these 41 CSOs. We defined organizations as religious/conservative if they (1) referred to religious values in their discourse and activities and/or (2) used a discourse that supported traditional values with respect to family, education, gender relations, and nation. We defined organizations as secular if they did not have the features in (1) and/or (2) or if they considered themselves to be defenders of secular principles. According to our categorization, almost half of the 41 CSOs in our data were religious/conservative while the rest were secular.

To test Hypothesis 3, we examined the 10 most frequently mentioned CSOs on Twitter between August 18 and September 17, 2019. Nine of the 10 most frequently mentioned CSOs were religious/conservative. Below, we closely examine the tweets about these 10 organizations, which constitute $35.76 \%$ of the entire data (Table 2 , Figure 2). Using words and n-grams, we analyzed the content of these tweets. 
insan \& toplum

Table 2

The Number of Tweets About the 10 Most frequently mentioned CSOs by Date

\begin{tabular}{|c|c|c|c|c|c|c|c|c|c|c|}
\hline Date & Ensar & Ülkü & TÜGVA & TÜRGEV & Furkan & Hüdayi & Fikıh & ADD & Yesevi & TEMA \\
\hline Aug18 & 14 & 0 & 1 & 0 & 2 & 2 & 0 & 0 & 0 & 5 \\
\hline Aug19 & 44 & 33 & 5 & 4 & 13 & 1 & 1 & 3 & 1 & 1 \\
\hline Aug20 & 35 & 137 & 1 & 1 & 66 & 0 & 0 & 0 & 3 & 8 \\
\hline Aug21 & 27 & 2 & 1 & 1 & 29 & 1 & 2 & 3 & 0 & 7 \\
\hline Aug22 & 23 & 4 & 1 & 0 & 105 & 1 & 2 & 1 & 3 & 47 \\
\hline Aug23 & 58 & 4 & 4 & 2 & 3 & 0 & 1 & 2 & 0 & 23 \\
\hline Aug24 & 43 & 398 & 33 & 0 & 2 & 2 & 0 & 43 & 0 & 18 \\
\hline Aug25 & 50 & 57 & 10 & 5 & 1 & 0 & 0 & 3 & 0 & 13 \\
\hline Aug26 & 45 & 6 & 3 & 10 & 1 & 0 & 3 & 4 & 0 & 22 \\
\hline Aug27 & 2028 & 460 & 932 & 785 & 3 & 597 & 3 & 35 & 286 & 20 \\
\hline Aug28 & 150 & 25 & 49 & 91 & 7 & 31 & 3 & 18 & 23 & 11 \\
\hline Aug29 & 38 & 5 & 9 & 19 & 7 & 4 & 1 & 13 & 10 & 11 \\
\hline Aug30 & 44 & 220 & 6 & 15 & 43 & 2 & 1 & 57 & 3 & 12 \\
\hline Aug31 & 29 & 20 & 6 & 3 & 3 & 2 & 0 & 24 & 0 & 5 \\
\hline Sep1 & 66 & 0 & 4 & 2 & 10 & 1 & 0 & 14 & 6 & 11 \\
\hline Sep2 & 33 & 0 & 4 & 11 & 23 & 18 & 2 & 6 & 12 & 8 \\
\hline Sep3 & 45 & 19 & 7 & 5 & 11 & 14 & 168 & 10 & 3 & 5 \\
\hline Sep4 & 44 & 4 & 5 & 15 & 28 & 2 & 435 & 15 & 2 & 4 \\
\hline Sep5 & 48 & 5 & 4 & 13 & 5 & 8 & 29 & 7 & 0 & 14 \\
\hline Sep6 & 35 & 4 & 2 & 1 & 121 & 1 & 12 & 8 & 1 & 2 \\
\hline Sep7 & 47 & 271 & 2 & 3 & 180 & 2 & 7 & 12 & 1 & 3 \\
\hline Sep8 & 36 & 5 & 3 & 7 & 15 & 2 & 3 & 6 & 0 & 5 \\
\hline Sep9 & 42 & 1 & 10 & 8 & 29 & 4 & 3 & 5 & 1 & 8 \\
\hline Sep10 & 35 & 11 & 13 & 5 & 2 & 0 & 3 & 4 & 0 & 6 \\
\hline Sep11 & 29 & 7 & 6 & 2 & 4 & 0 & 1 & 23 & 0 & 18 \\
\hline Sep12 & 29 & 9 & 13 & 2 & 2 & 3 & 1 & 10 & 1 & 3 \\
\hline Sep13 & 28 & 40 & 8 & 2 & 9 & 2 & 1 & 10 & 0 & 6 \\
\hline Sep14 & 28 & 11 & 4 & 3 & 3 & 1 & 0 & 4 & 0 & 2 \\
\hline Sep15 & 82 & 5 & 1 & 6 & 2 & 0 & 1 & 14 & 0 & 5 \\
\hline Sep16 & 65 & 36 & 5 & 20 & 2 & 1 & 1 & 5 & 0 & 11 \\
\hline Sep17 & 22 & 7 & 2 & 1 & 4 & 2 & 0 & 3 & 0 & 6 \\
\hline TOTAL & 3,342 & 1,806 & 1,154 & 1,042 & 735 & 704 & 684 & 362 & 356 & 320 \\
\hline
\end{tabular}




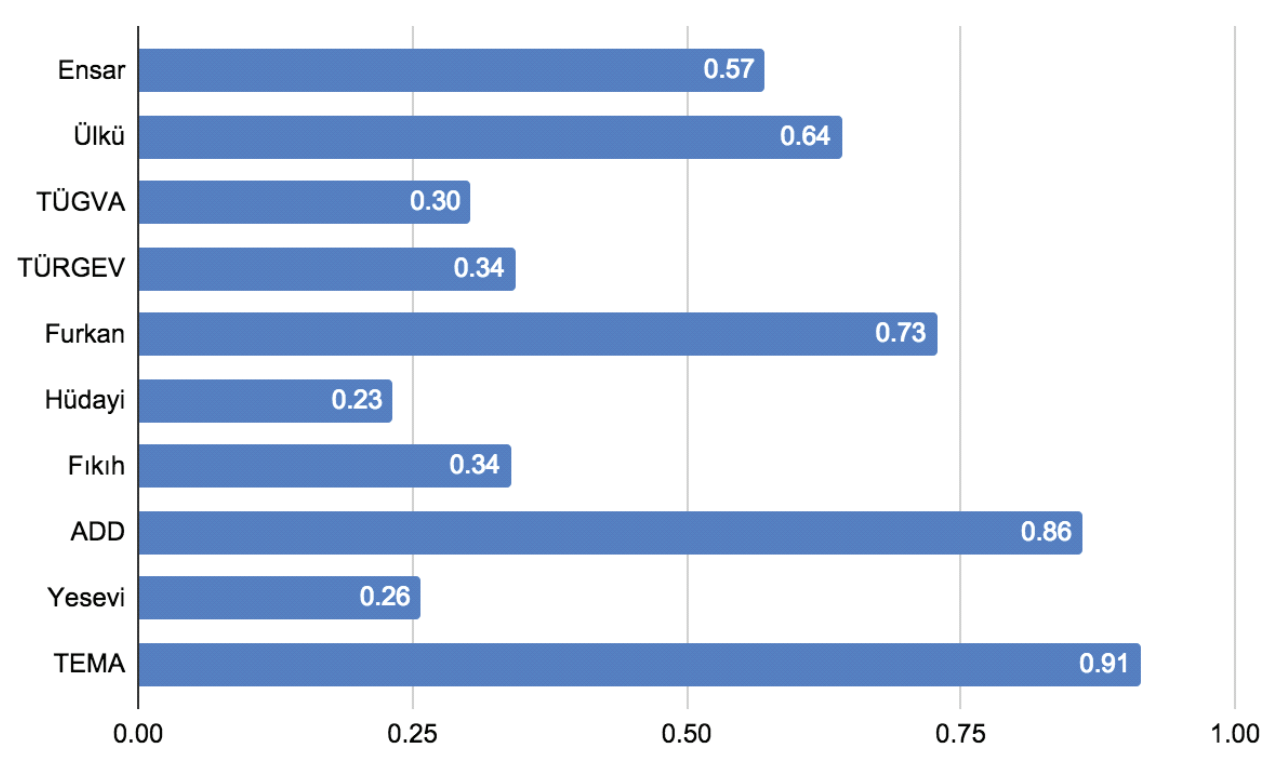

Figure 2. Relative entropies $\left(\mathrm{H}_{\mathrm{rel}}\right)$ of the 10 most frequently mentioned CSOs.

As Table 1 shows, the Ensar Foundation, which is a religious/conservative organization, was the most frequently mentioned CSO on Twitter ( $n=3,342$ ). Tweets about this organization accounted for $11.37 \%$ of the overall data. The fact that 4,941 CSOs were mentioned in tweets and that $11.37 \%$ of them came from a single foundation further supported Hypothesis 1. Yet, as Table 2 and Figure 2 show, the distribution of the tweets about Ensar over time was moderately even $\left(\mathrm{H}_{\text {rel }}=.57\right)$. Thus, this finding about the Ensar Foundation did not support Hypothesis $2 \mathrm{~b}$. We found that the most frequently used nouns in tweets about the Ensar Foundation were Ensar ( $\mathrm{n}=3,484)$, followed by TÜRGEV (972), TÜGVA (752), milyon "million” (739), Aziz Mahmud Hüdayi (509), İBB (418), Ekrem (391), İstanbul (384), and iptal "cancel" (377). The longest and most frequent n-gram was vakfı türgev aziz mahmud hüdayi vakfi (389), followed by various combinations of other CSOs, including TÜGVA, TÜRGEV, Hüdayi, Yesevi, and Dar'ül Fünun.

When we closely analyzed the tweets about the Ensar Foundation, we found that on August 27, the day on which the highest number of tweets was written, Twitter users discussed the cancellation of the Istanbul Metropolitan Municipality's (IBB) agreements with the Ensar Foundation alongside TÜGVA, TÜRGEV, Aziz Mahmud Hüdayi Vakfı, Hoca Ahmed Yesevi Vakfı, and Darül-Fünun İlahiyat Vakfı and by the newly elected mayor, Ekrem İmamoğlu. These CSOs are religious/ conservative organizations known for their close affiliation with the current Justice and Development Party (JDP, hereafter) government. IBB, which had been 
governed by a mayor from the JDP for the last 17 years, financially supported these organizations through the agreements mentioned in tweets. The new mayor, who was from the non-conservative Republican People's Party (CHP) and was supported by other main opposition parties such as İyi Party and People's Democratic Party (HDP), canceled all of these agreements in response to the increasing power of these organizations, attained through IBB's financial support. The reason why the tweets about the Ensar Foundation were written on this single day was that some of the Twitter users expressed their satisfaction with the decision of the new mayor. Conversely, those who were critical about the decision wrote tweets, thereby increasing the number of tweets about the Ensar Foundation. For example, the longest n-gram was followed by almost identical tweets from 238 different users, sent on the same day: August 27. The main argument of these tweets, as opposed to those supporting the decision, was that the cancellation of the agreement by the new mayor was targeting Islam and Muslims.

A more detailed analysis of the data from the TÜGVA, TÜRGEV, Aziz Mahmud Hüdayi Vakf1, Hoca Ahmed Yesevi Vakfı, and Darül-Fünun İlahiyat Vakfı showed that the content of the tweets about these CSOs was similar to those about the Ensar Foundation. Türkiye Gençlik Vakfı (The Turkey Youth Foundation, TÜGVA) was the third most frequently mentioned CSO, appearing in $3.93 \%$ of the data ( $\mathrm{n}=1,154)$, which supported Hypothesis 1 . As Table 2 and Figure 2 show, the distribution of the tweets about TÜGVA over time was uneven $\left(\mathrm{H}_{\text {rel }}=.30\right)$, which strongly supports Hypothesis $2 \mathrm{~b}$. The most frequently used nouns and phrases in tweets about TÜGVA were vakfi "foundation" (2,453), Ensar (983), TÜGVA (883), TÜRGEV (762), Aziz Mahmud Hüdayi (502), milyon tl “million Turkish liras” (375), Hoca Ahmed Yesevi (357), Dar'ül Fünun (338), and İBB (291), with the longest and most frequent n-gram being ensar vakfi türgev aziz mahmud hüdayi vakfi tügva darul fünun (265).

Türkiye Gençlik ve Eğitime Hizmet Vakfı (Turkey Youth and Education Service Foundation, TÜRGEV) was the fourth most frequently mentioned organization ( $\mathrm{n}=$ 1,042). The tweets about TÜRGEV constituted $3.55 \%$ of the data and were unevenly distributed over time (Table 2, Figure 2, $\mathrm{H}_{\text {rel }}=.34$ ), which supported Hypotheses 1 and $2 \mathrm{~b}$. The most frequently used nouns and phrases in the tweets about TÜGVA were vakf1 "foundation" (2,322), Ensar (1,044), TÜRGEV (1,027), TÜGVA (678), Aziz Mahmud Hüdayi (509), milyon tl "million Turkish liras" (425), Hoca Ahmed Yesevi (352), Dar'ül Fünun (339), and İBB (332), with the longest and most frequent n-gram being ensar vakfı türgev aziz mahmud hüdayi vakfı tügva darul (266). 
Aziz Mahmud Hüdayi Vakfı was the sixth most frequently mentioned organization ( $\mathrm{n}=704$ ). The tweets about Aziz Mahmud Hüdayi Vakfı constituted $2.4 \%$ of the data and were unevenly distributed over time (Table 2, Figure $2, \mathrm{H}_{\text {rel }}=$ .23), which supported Hypotheses 1 and 2b. The most frequently used nouns and phrases in the tweets about TÜGVA were vakf1 "foundation" (2,031), Ensar (681), TÜRGEV (643), Aziz Mahmud Hüdayi (538), TÜGVA (541), Hoca Ahmed Yesevi (349), milyon tl "million Turkish liras" (320), Dar'ül Fünun (338), and İBB (262), with the longest and most frequent n-gram being ensar vakfı türgev aziz mahmud hüdayi vakfı tügva darul (266).

Hoca Ahmed Yesevi Vakf1 was the ninth most frequently mentioned CSO ( $\mathrm{n}=$ 356). The tweets about Hoca Ahmed Yesevi Vakf1 constituted $1.21 \%$ of the data and were unevenly distributed over time (Table 2, Figure $2, \mathrm{H}_{\text {rel }}=.26$ ), which supported Hypotheses 1 and 2b. The most frequently used nouns and phrases in the tweets about this CSO were vakfi "foundation" (1,411), Hoca Ahmed Yesevi (371), Ensar (370), TÜRGEV (353), TÜGVA (344), Aziz Mahmud Hüdayi (340), Dar'ül Fünun (334), and milyon tl "million Turkish liras" (220), with the longest and most frequent n-gram being ensar vakfi türgev aziz mahmud hüdayi vakfı tügva darul (266).

There were five more organizations among the 10 most frequently mentioned CSOs but were not related to the above five. Of them, Ülkü Ocakları Eğitim ve Kültür Vakfı (the Idealist Clubs Educational and Cultural Foundation, Ülkü) was the second most frequently mentioned CSO $(n=1,806)$. Ülkü Ocakları Eğitim ve Kültür Vakfı, which has a very close relationship to the Nationalist Movement Party (MHP), which itself strongly supports the JDP government, is a religious/ conservative organization. The tweets about this CSO accounted for $6.15 \%$ of the overall data, which supported Hypothesis 1. Moreover, as Table 2 and Figure 2 show, the distribution of the tweets about Ülkü Ocakları Eğitim ve Kültür Vakfı over time was even $\left(\mathrm{H}_{\text {rel }}=.64\right)$, which did not support Hypothesis $2 \mathrm{~b}$. The most frequently used nouns and phrases were ülkü ocakları eğitim ve kültür $(1,848)$, genel "general" (1,736), sayın "Mr." (1,325), yeni "new" (1,231), binasinın "of its building" $(1,140)$, merkez "center" $(1,033)$, and the head of the Nationalist Movement Party Devlet Bahçeli (922), which together created the longest and most frequent n-gram, devlet bahçelinin teşrifleriyle gerçekleştireceğimiz ülkü ocakları eğitim ve kültür vakfının yeni genel merkez binasının "the new center of the Idealist Clubs Educational and Cultural Foundation would be [opened] by Devlet Bahçeli" (893). This was followed by Bilgetürk (567), a journal of the organization. Although the highest number of tweets about Ülkü Ocakları 
Eğitim ve Kültür Vakfı was written on August 27, these tweets were about the opening of the organization's new head office (the longest n-gram above). All of the tweets about this organization were related to the organization's activities and publications, such as courses, books, and journals (e.g., Bilgetürk (567)). In other words, tweets about this organization were not particularly political, unlike tweets about the other most frequently mentioned organizations, such as Ensar, TÜGVA, and TÜRGEV.

Furkan Vakf1, which is a religious/conservative organization but is critical of the JDP government, was the fifth most frequently mentioned CSO ( $\mathrm{n}=735$ ). Tweets about this organization constituted $2.5 \%$ of the data and were relatively evenly distributed over time (Table 2, Figure 2, $\mathrm{H}_{\text {rel }}=.73$ ), which supported Hypothesis 1 but not Hypothesis 2b. The most frequently used nouns and phrases in tweets about Furkan Vakfi were Furkan (751) and Vakfi (673), followed by Alparslan Kuytul (273), tahliye "release" (221), and başkanı "its president" (214). The longest and the most frequent n-gram was alagözü tahliye ederek sanki adalet varmış gibi yapanlar bilsinler ki bu dava sus davasıdır "those who released Alagözü from the prison should know that this trial is a 'shut-up' trial” (37). Furkan Vakfi was disbanded in 2018 as a result of various allegations, such as that it had supported the coup attempt on June 15, 2016. The organization's president, Ali Alagöz, and one of the most important figures in the organization, Alparslan Kuytul, were in prison during the data collection process. Our close reading of the tweets about this organization revealed that all of the tweets were about the court process involving these people.

Fıkıh Araştırmaları Derneği (the Association for the Islamic Law Studies, Fikıh-Der), which is a religious/conservative organization, was the seventh most frequently mentioned CSO ( $\mathrm{n}=684$ ). Tweets about Fıkıh Derneği constituted $2.33 \%$ of the data and were unevenly distributed over time (Table 2, Figure $2, \mathrm{H}_{\text {rel }}$ $=.34$ ), which supported Hypotheses 1 and $2 \mathrm{~b}$. The most frequently used nouns and phrases in the tweets about Fikıh-Der were Flkıh (707), derneği "association" (2,031), tecavüz "rape" (596), erkek "man” (580), and \#gazetesozcu "Sözcü newspaper" (568). The longest and most frequent n-gram was erkek çocuklarına tecavüz edilen fikıh derneği neden 2013 yılında kuruldu biliyor musunuz "Did you know why the Fikıh-Der where boys were raped was founded in 2013?" (537), which was the title of a column written in the Sözcü newspaper by Yilmaz Özdil, a journalist who is very critical of the JDP government. In his column, Özdil strongly criticized the JDP's policies regarding religious education in Turkey. 
A great majority of tweets mentioning Fikıh-Der were written on September 3 (168) and September 4 (434). The reason for the increase in the number of tweets about this organization on those two days, as the longest and most frequent n-gram also reveals, was the spread of the news about the sexual harassment of children by teachers in one of the Quran courses of this organization. Not surprisingly, almost all of the tweets were critical of the organization. As the most frequent n-gram indicates, these critical views turned into criticisms of the JDP government.

Fıkıh-Der was followed by Atatürkçü Düşünce Derneği (The Atatürkist Thought Association, ADD), which is a secular and Kemalist organization ( $\mathrm{n}=$ 362 ). A total of $1.23 \%$ of the tweets in the data mentioned ADD, which supported Hypothesis 1 . However, as Table 2 and Figure 2 show, the data were distributed relatively evenly over time $\left(\mathrm{H}_{\mathrm{rel}}=.86\right)$, which did not support Hypothesis $2 \mathrm{~b}$. The most frequently used nouns and phrases in the tweets about ADD were Atatürkçü Düşünce Derneği (343) and ADD (87). The longest and most frequent n-grams were \#diyanetkapatılsın [...] asıl atatürkçü düşünce derneği kapatılsın "ADD should be shut down instead of Diyanet" (21) and traş olması cilt hastalığını tetikliyor raporu yoksa sakal "If he has a medical excuse that shaving causes skin problems..." (21). A closer examination of the data revealed that, in addition to the tweets about ADD's activities, there were tweets including negative views about ADD, as evidenced by the longest n-grams. A group of Twitter users, who were critical of ADD, wrote that ADD should be shut down instead of the Turkish Presidency of Religious Affairs (Diyanet for short). These users criticized the ideology represented by ADD, which supports the closing of religious organizations, such as Diyanet, in Turkey, which is a constitutionally secular country. Another group of Twitter users, who were critical of ADD, argued against ADD's suggestion that as beards symbolize Islamic fanaticism, bearded city bus drivers should not work for the IBB.

Türkiye Erozyonla Mücadele Vakfı (The Turkish Foundation for Combating Soil Erosion, for Reforestation and the Protection of Natural Habitats, TEMA) was the tenth most frequently mentioned CSO $(n=320)$. A total of $1.09 \%$ of the tweets mentioning CSOs were about TEMA, which supported Hypothesis 1 . However, as Table 2 and Figure 2 show, the data were distributed relatively evenly over time $\left(\mathrm{H}_{\text {rel }}=.91\right)$, which did not support Hypothesis $2 \mathrm{~b}$. The most frequently used nouns were TEMA (379), vakfi "foundation" (249), fidan "young tree/plant" (145), destek "support" (55), Izmir (47), and orman "forest" (30). The longest and most frequent n-grams were tema vakfı izmir için fidan bağışlarınızı bekliyoruz "We [TEMA] are 
waiting for your donations for plantation in Izmir (after the forest fires)" (15) and tema vakfi 27 yıl önce bugün kuruldu "TEMA was founded 27 years ago today" (10). These findings indicate that, unlike tweets about Islamic/conservative or secular organizations such as TÜGVA, TÜRGEV, and ADD, those about TEMA aimed mainly to inform people about the organization's activities.

\section{Discussion and Conclusion}

In this study, we investigated the coverage of CSOs on Twitter by focusing on the most frequently mentioned organizations and their characteristics. We also examined the effects that social and political developments in Turkey had on the coverage of CSOs. The major findings of this research can be summarized as follows: First, a small number of CSOs were mentioned on Twitter, supporting Hypothesis 1. Second, tweets about the CSOs were not equally distributed in number across the CSOs, supporting Hypothesis 2a. Third, tweets about some of the CSOs were not equally distributed in number over time, partially supporting Hypothesis $2 \mathrm{~b}$. Among the 10 most frequently mentioned CSOs, tweets about TÜGVA, TÜRGEV, Hüdayi, Fikıh-Der, and Yesevi were unevenly distributed over time, supporting Hypothesis 2b. However, the number of tweets about Ensar, Ülkü, Furkan, ADD, and TEMA was relatively evenly distributed over time, not supporting Hypothesis 2b. Fourth, most of the tweets about CSOs included politically polarized views about the organizations in Turkey, supporting Hypothesis 3. Having summarized the findings, we now discuss them below.

CSOs are important agents of democracy and the media helps them carry out their democratic functions. In countries such as Turkey, where CSOs cannot participate in decision-making processes at the political level (YADA, 2014), the media is important, especially with regard to the digital activism as well as the formation of public opinion on certain issues. Social media gives CSOs a significant opportunity to fulfill their democratic functions, as it allows them to quickly share knowledge and create awareness. It also provides them with a means of engaging in two-way communication with people. The present study showed that a small number of CSOs were mentioned on social media in Turkey, indicating that social media is not yet a fertile ground on which CSOs can fulfill their democratic functions.

As mentioned previously, Twitter is a highly polarized media tool in Turkey, one on which political divisions can easily be observed (Bulut \& Yörük, 2017; 
Hatipoğlu et al., 2016). Although the present research did not aim to identify the ideological stances of Twitter users, the characteristics of the most frequently mentioned CSOs indicate that Twitter is polarized in terms of CSOs. Eight of the 10 most frequently mentioned organizations-Ensar, Ülkü, TÜGVA, TÜRGEV, Furkan, Hüdayi, Fıkıh, and Yesevi-were strictly religious/conservative, while ADD was the only organization with a clearly strict secular and Kemalist ideology. TEMA, while secular, was the only one among the 10 most frequently mentioned CSOs which did not have an open political ideology. Moreover, five of the 10 most frequently mentioned CSOs-Ensar, TÜGVA, TÜRGEV, Hüdayi, and Yesevi-were religious/conservative organizations with close relations to the governing JDP, while ADD is known for its strictly critical attitude toward the JDP. Additionally, the finding that the distribution of the tweets about most of these CSOs was not even over time indicated that political developments in Turkey, especially tensions between the JDP, and opposition parties and groups, shaped the tweets about these CSOs. In other words, most of the tweets mentioning these CSOs reflected the opinions of either supporters or opponents of the ideologies that these CSOs represented, which in turn makes Twitter a polarized space for CSOs in Turkey.

However, not all the tweets about CSOs with clear ideologies were polarized in the same manner. While Furkan is a religious/conservative organization but anti-JDP at the same time, most of the tweets about this organization included information about the court processes involving the organization's important figures, who had been imprisoned for a while. Still, the tone of tweets about this organization implied that the decision to shut down Furkan was political and unfair. Similarly, all the tweets about Ülkü Ocakları Eğitim ve Kültür Vakfı, which is a religious/conservative organization, were about the organization's activities and publications.

The findings of this research are in line with the previous research on the relationship among social media, political polarization, and CSOs. Twitter is a democratic space which enables different voices to be heard without any restrictions (Bekafigo \& McBride, 2013). However, Twitter is also a space in which people both reflect and reproduce existing polarization by refraining from opinions with which they disagree (Şener et al., 2015) and by writing in a disrespectful and angry manner (Tucker et al., 2018; And1 et al., 2019). Furthermore, what people write about certain issues on Twitter is strongly linked to what happens at the political level. This is because polarization among the political elites is very likely to shape 
individuals' opinions, which in turn increases the polarization among the masses (Körösényi, 2013). Turkey, is a country that is highly polarized along certain political and cultural ideologies (Erdoğan \& Semerci-Uyan, 2018; Somer, 2019). For example, newspapers in Turkey are polarized in terms of their representations of the news about CSOs (Akboga and Arik, 2019). Other research also showed that in Turkey the tensions between the political camps to which people belong strongly influence what they write on Twitter (Hatipoğlu et al., 2016). Our findings indicate that political developments in Turkey, especially tensions between the JDP and opposition parties and groups, shaped the tweets about the CSOs that are considered as the advocates of the ideologies represented by these parties. This finding indicates that similar to the tweets about many issues in Turkey, those about CSOs, which are expected to reduce the tensions in society, are not exempt from political polarization.

In this study, we showed that Twitter is a polarized space in terms of the ways in which people talk about CSOs in Turkey. Future research may look at other social media tools such as Facebook and Instagram to further examine this topic. Here we used the keywords derneği "association" and vakfi "foundation" in accusative forms to investigate which CSOs were mentioned on Twitter in Turkey. However, there could have been other tweets that used abbreviations instead of these keywords. Although it would be time-consuming, a future study may use the full names, shortened names, and abbreviations of all the CSOs as keywords to further examine the representations of CSOs on social media. Additionally, we collected data for only 31 days and observed that the number of tweets per day and per CSO could be influenced by social and political developments. For example, in our data, Twitter users reacted to the IBB's decision to not fund a group of religious/conservative CSOs on August 27, 2019. Therefore, there is a need to collect data for a longer period of time and thereby investigate whether similar types of social and political developments always have an impact on the coverage of CSOs on Twitter. This is one line of research that we are currently pursuing. Furthermore, in this study, we collected data in which Twitter users mentioned any kind of CSO. However, CSOs themselves use social media to make connections with their supporters and to inform the public about their activities. Therefore, another line of research we are currently pursuing will focus on tweets written by CSOs. 


\section{References}

Abramowitz, A. I., \& Saunders, K. L. (2008). Is polarization a myth? The Journal of Politics, 70(2), 542-555.

Akboğa, S., \& Arık, E. (2018). Türkiye'de sivil toplum kuruluşlarının medyada görünürlüğü [Media publicity of civil society organizations in Turkey]. The Journal of Humanity and Society, 8(1), 37-65. doi: 10.12658/ M0224

Akboga, S., \& Arik, E. (2019). The ideological convergence of civil society organizations and newspapers in Turkey. Voluntas: International Journal of Voluntary and Nonprofit Organizations. Advanced online publication. doi: 10.1007/s11266-019-00144-1

Anagnostopoulos, C., Gillooly, L., Cook, D., Parganas, P., \& Chadwick, S. (2016). Stakeholder communication in 140 characters or less: A study of community sport foundations. Voluntas: International Journal of Voluntary and Nonprofit Organizations, 28(5), 2224-2250. doi: 10.1007/s11266-016-9802-4

Andı, S., Aytaç, S. E., \& Çarkoğlu, A. (2019). Internet and social media use and political knowledge: Evidence from Turkey. Mediterranean Politics, 1-21. doi:10.1080/13629395.2019.1635816

Andrews, K. T., \& Caren, N. (2010). Making the news: Movement organizations, media attention, and the public agenda. American Sociological Review, 75(6), 841-866. doi: 10.1177/0003122410386689

Anthony, L. (2018). AntConc (Version 3.5.7) [Computer Software]. Tokyo, Japan: Waseda University. Retrieved from http://www.laurenceanthony.net/software

Aydın-Duzgit, S., \& Balta, E. (2019). When elites polarize over polarization: Framing the polarization debate in Turkey. New Perspectives on Turkey, 59(1), 153-176.Barberá, P., \& Metzger, M. M. (2013, June 3). Twitter and the Turkish protests: Post-weekend update [Blog post]. Retrieved from https:// themonkeycage.org/2013/06/twitter-and-the-turkish-protests-post-weekend-update/

Bekafigo, M. A., \& McBride, A. (2013). Who tweets about politics? Political participation of Twitter users during the 2011 gubernatorial election. Social Science Computer Review, 31(5), 625-643. doi: $10.1177 / 0894439313490405$

Bortree, D. S., \& Seltzer, T. (2009). Dialogic strategies and outcomes: An analysis of environmental advocacy groups' Facebook profiles. Public Relations Review, 35(3), 317-319. doi: 10.1016/j.pubrev.2009.05.002

Bozkanat, E. (2020). Sivil Toplum kuruluşlarının sosyal medyada ilişki kurma ve iletişim stratejileri: Yeşilay Türkiye Facebook sayfası örneği. Erciyes İletişim Dergisi, 7(1), 149-168.

Bruns, A. (2011). How long is a Tweeter? Mapping dynamic conversation networks on Twitter using Gawk and Gephi. Information, Communication, and Society, 15(9), 1323-1351. doi: 0.1080/1369118X.2011.635214

Bulut, E., \& Yörük, E. (2017). Digital populism: Trolls and political polarization of Twitter in Turkey. International Journal of Communication, 11, 4093- 4117.

Chalmers, A. W., \& Shotton, P.A. (2016). Changing the face of advocacy? Explaininginterestorganizations' use of social media strategies. Political Communication, 33(3), 374-391. doi: 10.1080/10584609.2015.1043477

Clement, J. (2019, November 20). Leading countries based on number of Twitter users as of October 2019. Retrieved from https://www.statista.com/statistics/242606/number-of-active-twitter-users-inselected-countries/

Çetinkaya, A., Şahin, Ö.E., \& Kırık, A. L. (2014). A research on social and political use of social media in Turkey. International Journal of Science Culture and Sport, 2(8), 49-60. doi: 10.14486/IJSCS207

Çobanoğlu, Y. (2019). Değişen kamusallığın yeni "siyaset yapma” mekanı olarak sosyal medya - (Politik kimlikler ve kamusal haklar ilişkisi bağlamında Twitter örneği) [Social media as the new venue of "political activity" of the changed publicity - (The case of Twitter in the context of the relations between political identities and public rights)]. Uluslararası Toplum Araştırmaları Dergisi, 10(17), 696-737. doi: 10.26466/ opus.520312

Depeli, G. (2014). Anayasa yazım sürecine LGBT müdahilliğinin merkez medyadaki görünümü [The View of the intervening of LGBT (Lesbian Gay Bisexual And Transgender) on the constitution writing process]. Galatasaray Üniversitesi İletişim Dergisi, 18, 37-60. 
Deren Van Het Hof, S. (2014). The media publicity of NGOs in Turkey. European Journal of Research on Social Studies, 1(1), 108-114.

Doğu, B. (2017). Turkey's news media landscape in Twitter: Mapping interconnections among diversity. Journalism, 1-9. doi:10.1177/1464884917713791

Doğu, B., \& Mat, H.O. (2019). Who sets the agenda? Polarization and issue ownership in Turkey's political twittersphere. International Journal of Communication, 13, 229-250.

Diamond, L. (1994). Rethinking civil society: Toward democratic consolidation. Journal of Democracy, 5(3), 4-17.

doi: 10.1353/jod.1994.0041

Dodge, J. (2015). The deliberative potential of civil society organizations: Framing hydraulic fracturing in New York. Policy Studies, 36(3), 249-266. doi: 10.1080/01442872.2015.1065967

Doğu, B., Özçetin, B., Bayraktutan, G., Binark, M., Çamu, T., Telli Aydemir, A., \& İslamoğlu, G. (2014). Siyasetin yeni hali: Vaka-i sosyal medya. İstanbul, Turkey: Kalkedon.

Dondurucu, Z. B. (2014). Sivil toplum kuruluşlarının sosyal medya üzerinden halkla ilişkiler çalışmaları ö [The public relations affairs of civil society organizations in social media] (Unpublished master's thesis). İstanbul Üniversitesi, İstanbul, Turkey.

Duggan, M., \& Smith, A. (2016) The political environment on social media. Pew Research Center.

Erdoğan, E., \& Uyan Semerci, P. (2018). Fanus'ta diyaloglar: Türkiye'de kutuplaşmanın boyutları [Dialogues in bell glass: The dimensions of polarization in Turkey]. Istanbul, Turkey: Bilgi Universitesi Yayınları.

Fiorina, M. P. , Abrams, S. A., \& Pope, J. C. (2008). Polarization in the American public: Misconceptions and misreadings. The Journal of Politics, 70(2), 556-560.

Foa, R. S., \& Ekiert, G. (2017). The weakness of post-communist civil society re-assessed. European Journal of Political Research, 56(2), 419-439. doi: 10.1111/1475-6765.12182

Gao, F. (2016). Social media as a communication strategy: Content analysis of top nonprofit foundations' micro-blogs in China. International Journal of Strategic Communication, 10(4), 255-271. doi: 10.1080/1553118X.2016.1196693

General Directorate of Civil Society Relations (2019). The number of associations. Retrieved from https:// www.siviltoplum.gov.tr/dernek-sayilari

General Directorate of Foundations (2019). Distribution of new foundations by years. Retrieved from https://cdn.vgm.gov.tr/genelicerik/genelicerik_945_290519/03-yeni-vakiflarin-yil-ba.pdf

Greenberg, J., \& MacAulay, M. (2009). NPO 2.0? Exploring the web presence of environmental nonprofit organizations in Canada. Global Media Journal_Canadian Edition, 2, 63-88.

Greenberg, J., \& Walters, D. (2004). Promoting philanthropy? News publicity and voluntary organizations in

Canada. Voluntas: International Journal of Voluntary and Nonprofit Organizations, 15(4), 383-404. doi: 10.1007/s11266-004-1238-6

Gries, S. Th. (2015). Quantitative designs and statistical techniques. In D. Biber \& R. Reppen (Eds.), The Cambridge Handbook of English Corpus Linguistics (pp. 50-71). Cambridge: Cambridge University Press.

Gümüş, N., \& Ağaçcı, L. (2018). Sivil toplum örgütlerinin pazarlama iletişiminde sosyal medya kullanımı: Kızılay ve Yeşilay üzerinde bir araştırma. Üçüncü Sektör Sosyal Ekonomi, 53(2), 637-661.

Güran Yiğitbaşı, K. (2016). Medya ve mültecileri sivil toplum üzerinden okumak: Mülteci-Der örneği [Understanding media and refugees through civil society: Mülteci-Der case]. Marmara İletişim Dergisi, 25, 53-76. doi: 10.17829/midr.20162520717

Hale, M. (2007). Superficial friends: A content analysis of nonprofit and philanthropy coverage in nine major newspapers. Voluntas: International Journal of Voluntary and Nonprofit Organizations, 36(3), 465-486. doi: $10.1177 / 0899764006296849$

Hatipoğlu, E., Gökçe, O. Z., Dinçer, B., \& Yücel, S. (2016). Sosyal medya ve Türk dış politikası: Kobani 
tweetleri üzerinden Türk diş politikası algısı [Social media and Turkish foreign policy: Turkish foreign policy perceptions through Kobane tweets]. Uluslararası İliş̧kiler, 13(52), 175-89.

Hatipoğlu, E., Gökçe, O. Z., Arın, İ., \& Yücel, S. (2019). Automated text analysis and international relations: The introduction and application of a novel technique for Twitter. All Azimuth, 8(2), 183-204. doi: 10.20991/allazimuth.476852

Helmig, B., Spraul, K., \& Tremp, K. (2012). Replication studies in nonprofit research: A generalization and extension of findings regarding the media publicity of nonprofit organizations. Nonprofit and Voluntary Sector Quarterly, 41(3), 360-385. doi: 10.1177/0899764011404081

Hetherington, M. J. (2001). Resurgent mass partisanship: The role of elite polarization. American Political Science Review, 95(3), 619-631.

Joyce, M. (2010). Introduction: How to think about digital activism. In M. Joyce (Ed.), Digital activism decoded: The new mechanics of change (pp. 1-14). NY: Ideabate Press.

Kim, D., Chun, H., Kwak, Y., \& Nam, Y. (2014). The employment of dialogic principles in website, Facebook, and Twitter platforms of environmental nonprofit organizations. Social Science Computer Review, 32(5), 590-605. doi: 10.1177/0894439314525752

Körösényi, A. (2013). Political polarization and its consequences on democratic accountability. Cornivus Journal of Sociology and Social Policy, 4(2), 3-30.

Lam, W.F., \& and Nie, L. (2020). Online of offline? Non-profits' choice and use of social media in Hong

Kong. Voluntas: International Journal of Voluntary and Nonprofit Organizations, 31(1), 111-128. doi: 10.1007/ s11266-019-00128-1

Lee, T. E., Chen, J. Q., \& Zhang, R. D. (2001). Utilizing the Internet as a competitive tool for non-profit organizations. Journal of Computer Information Systems, 41(3), 26-31.

Levendusky, M. S. (2010). Clearer cues, more consistent voters: A benefit of elite polarization. Political Behaviour, 32(1)111-131.

Lovejoy, K., \& Saxton, G. (2012). Information, community, and action: How nonprofit organizations use social media. Journal of Computer-Mediated Communication, 17(3), 337-353. doi: 10.1111/j.10836101.2012.01576.x

Lovejoy, K., Waters, R. D., \& Saxton, G. D. (2012). Engaging stakeholders through Twitter: How nonprofit organizations are getting more out of 140 characters or less. Public Relations Review, 38(2), 313-318. doi: 10.1016/j.pubrev.2012.01.005

Marberg, A., van Kranenburg, H., \& Korzilus, H. (2016). NGOs in the news: The road to taken-for-grantedness. Voluntas: International Journal of Voluntary and Nonprofit Organizations, 27(6), 2734-2763. doi: 10.1007/ s11266-016-9757-5

McCoy, J., Rahman, T., \& Somer, M. (2018). Polarization and the global crisis of democracy: Common patterns, dynamics, and pernicious consequences for democratic polities. American Behavioral Scientist, 62(1), 16-42.

Miller, D. (2011). Nonprofit organizations and the emerging potential of social media and internet resources. SPNHA Review, 6(1), 32-52.

Nah, S., \& Saxton, G. D. (2012). Modeling the adoption and use of social media by nonprofit organization. New Media \& Society, 15(2), 294-313. doi: 10.1177/1461444812452411

Obar, J. A., Zube, P., \& Lampe, C. (2012). Advocacy 2.0: An analysis of how advocacy groups in the United States perceive and use social media as tools for facilitating civic engagement and collective action. Journal of Information Policy, 2, 1-15. doi: 10.5325/jinfopoli.2.2012.0001

Onat, F. (2010). Bir halkla ilişkiler uygulama alanı olarak sosyal medya kullanımı: Sivil toplum örgütleri üzerine bir inceleme [Social media practices as a public relations application field: An analysis about nongovernmental organizations]. İletişim: Kuram ve Araştırma Dergisi, 31, 103-121.

Örselli, E. (2016). Türkiye'de yargiya güven [Trust in judiciary in Turkey]. Konya: Çizgi Kitabevi. 


\section{insan \& toplum}

Öztürk, M. C., \& Şardağı, E. (2018). Kurumsal kimlik aracı olarak Facebook: Türkiye'de sivil toplum kuruluşları (STK) üzerine bir değerlendirme. Galatasaray Üniversitesi İletişim Dergisi, 28, 115-141.

Paxton, P. (2002). Social capital and democracy: An interdependent relationship. American Sociological Review, 62(2), 254-277. doi: 10.2307/3088895

Putnam, R. (2000). Bowling alone: The collapse and revival of American community. New York: Simon \& Schuster.

Saatçioğlu, E. (2017). Sivil toplum örgütlerinin sosyal medya kullanımları: Greenpeace Türkiye Facebook sayfası örneği [Social media usage of non-governmental organizations: Example of Greenpeace Turkey Facebook page]. Selçuk Üniversitesi İletişim Fakültesi Akademik Dergisi, 10(1), 158-187.

Sahin, O., \& Akboga, S. (2019). Ethnic identity and perceptions of the police in Turkey: The case of Kurds and Turks. Policing and Society, 29(8), 985-1000.

Seoa, H., Kim, J. Y., \& Yanga, S. (2009). Global activism and new media: A study of transnational NGOs' online public relations. Public Relations Review, 35(2), 123-126. doi: 10.1016/j.pubrev.2009.02.002

Somer, M. (2019). Turkey: The slippery slope from reformist to revolutionary polarization and democratic breakdown. ANNALS of the American Academy of Political and Social Science, 681(1), 42-61. doi: $10.1177 / 0002716218818056$

Sunstein, C. (2001). Republic.com. Princeton, NJ: Princeton University Press.

Şardağı, E. (2017). Sosyal medyada kurumsal kimlik: Türkiye'deki vakıf ve derneklerin Twitter kullanımının değerlendirmesi [Corporate identity in social media: The evaluation of Twitter usage of foundations and associations in Turkey]. Uşak Üniversitesi Sosyal Bilimler Dergisi, 10(3), 337-362.

Şener, G., Ogün Emre, P., \& Akyıldız, F. (2015). Türkiye'de sosyal medyanın siyasi katılıma etkileri [Effects of social media on political participation in Turkey]. Folklor, 21(81), 75-98.

Thornton, J. (2006). Nonprofit fund-raising in competitive donor markets. Nonprofit and Voluntary Sector Quarterly, 35(2), 204-224. doi: 10.1177/0899764005285951

Tucker, J. A., Guess, A., Barberá, P., Vaccari, C., Siegel, A., Sanovich, S., Stukal, D., \& Nyhan, B. (2018). Social media, political polarization, and political disinformation: A review of the scientific literature. Hewlett Foundation. doi: 10.2139/ssrn.3144139

Türkiye Üçüncü Sektör Vakfı (TÜSEV). (2013). Sivil toplum izleme raporu 2012 [Civil society monitoring report]. İstanbul: TÜSEV Yayınları.

Waisbord, S. (2011). Can NGOs change the news? International Journal of Communication, 5, 142-165.

Walker, M., Kent, A., \& Vincent, J. (2010). Communicating socially responsible initiatives: An analysis of US professional teams. Sport Marketing Quarterly, 19(4), 187-195.

Waters, R. D., \& Jamal, J. Y. (2011). Tweet, tweet, tweet: A content analysis of nonprofit organizations' Twitter updates. Public Relations Review, 37(3), 321-324. doi: 10.1016/j.pubrev.2011.03.002

Waters, R. D., \& Tindall, N. T. J. (2011). Exploring the impact of American news coverage on crisis fundraising: Using media theory to explicate a new model of fundraising communication. Journal of Nonprofit \& Public Sector Marketing, 23(1), 20-40. doi: 10.1080/10495142.2010.494875

Waters, R. D., \& Williams, J. M. (2011). Squawking, tweeting, cooing, and hooting: Analyzing the communication patterns of government agencies on Twitter. Journal of Public Affairs, 11(4), 353-363. doi: 10.1002/pa.385

Yardımc1-Geyikçi, Ş. (2014). Gezi-Park protests in Turkey: A party view politics. The Political Quarterly, 85(4), 445-453.

Yardi, S., \& Boyd, D. (2010). Dynamic debates: An analysis of group polarization over time on Twitter. Bulletin of Science Technology \& Society, 30(5), 316-327. doi: 10.1177/0270467610380011

YADA. (2014). Sivil toplum kuruluşlarına yönelik algı ve yaklaşımlar [Perceptions and approaches to civil society organizations]. İstanbul, Turkey: Taze Baskı. 
Young, J. A. (2017). Facebook, Twitter, and Blogs: The adoption and utilization of social media in nonprofit human service organizations. Human Service Organizations: Management, Leadership \& Governance, 41(1), 44-57. doi: 10.1080/23303131.2016.1192574

Zhou, H., \& Pan, Q. (2016). Information, community, and action on Sina-Weibo: How Chinese philanthropic NGOs use social media. Voluntas: International Journal of Voluntary and Nonprofit Organizations, 27(5), 2433-2457. doi: 10.1007/s11266-016-9685-4 